\title{
Assessment of Workers' Knowledge toward Occupational Hazards in Tiles Factories at Assiut Governorate
}

\author{
Mariam N. Fouad ${ }^{1}$, Soad A. Sharkawy ${ }^{2}$ \& Fayza M. Mohammed ${ }^{3}$. \\ 1. Nursing Specialist in the Technical Secondary of Nursing School for Girls at Assiut City, Egypt. \\ 2. Assistant Professor of Community Health Nursing, Faculty of Nursing- Assiut University, Egypt. \\ 3. Lecturer of Community Health Nursing, Faculty of Nursing- Assiut University, Egypt.
}

\begin{abstract}
Occupational health and safety is an important issue because of high rates of associated morbidity and mortality of exposed workers to occupational hazardous. Aim: This study aimed to assess workers' knowledge about Occupational Health Hazard in Tiles Factories at Assiut Governorate .Research design: Descriptive cross-sectional research design was carried out in this study. Setting: The study was carried out in tile factories at Assiut Governorate. It included four (4) industrial cities namely: Arab El Awamer city in Abnoub El_Safa city in BinyGhalib, El_Zrapy city inAboteg a factory ,Dashlout in Dirout factories. Sample:total coverage sample(400) of workers from the previous setting.Tools of the study:-Interview questionnaire sheet which developed by researcher after reviewing the relevant literature .Results:Finding revealed that $58.3 \%$ of the studied sample have poor knowledge about occupational health hazards in tile factories There were statistical significant difference between the total score of the studied sample knowledge about occupational health hazardous and studied sample age, marital status, level of education Conclusion: More than half of the studied sample have poor knowledge about occupational health hazards in tile factories. Recommendation:The study recommended that, Provide education \&training programs should be carried out regularly, special for using of personal protective equipment.
\end{abstract}

\section{Keywords: Tiles \& Occupational Hazards.}

\section{Introduction}

Tile is usually flat piece of hard clay, stone, or other material that is used for covering walls, floors, etc .The raw materials used to form tile consist of clay minerals mined from the earth's crust, natural minerals such as feldspar that are used to lower the firing temperature, and chemical additives required for the shaping process (Wadho,2012).

There are many toxic elements in tiles' materials such as cadmium, lead copper, arsenic, iron zinc and traces of other elements. The two most abundant toxic elements were lead and cadmium. Occupational heavy metal toxicity is still a health problem in many countries such as Egypt and Turkey. Although there are numerous industries which use lead based raw materials that may expose health risks to workers (Abd El Maaboud et al., 2015).

The workplace in tiles factories is the most common source of cadmium exposure, occurring mainly through inhalation of dust and fumes Cadmium principally affects the lung, kidney, liver, and testes following acute intoxication, which leads to nephrotoxicity due to prolonged exposure Cadmium is a potent cell poison and which causes oxidative stress by increasing lipid per oxidation and/or by changing intracellular glutathione levels. Inhalation exposure can result in acute hepatic and renal injury, while intake of cadmium- contaminated food causes acute gastrointestinal effects, such as nausea, vomiting and diarrhea ( Abd El Maaboud et al., 2015).

Lead increases the permeability of the blood-brain barrier and causes disruption, allowing large molecules such as albumin to enter the brain which increase osmotic pressure and causes ions and water to follow, resulting in edema of the brain and increase in intracranial pressure. Neurological complaints of workers that may be related to lead exposure such as tremors and numbness (Ashraph et al., 2013).

Health hazards among workers in tile factories may include respiratory hazards, toxicity, and exposure to noise, accidents, cardiovascular hazards, and stress. Pulmonary diseases in tiles industry are among the common causes of absence from work and early retirement in working populations. These diseases are responsible for $14 \%$ of work day loss among men (Environmental Health \& Safety Guidelines, 2013).

The overall prevalence rate of accidents in tile factories in India was $18.5 \%$. It was found that almost around $86 \%$ of the accidents had affected the limbs (upper limb $24.7 \%$, lower limb 61\%), superficial injuries like cuts, abrasions, and so on, contributed to a majority of the injuries $(52 \%), 40 \%$ of the accidents were due to stepping/striking against objects and while handling. Hand tools and machinery in motion contributed to around $20 \%$ of the accidents. Slip and falls accidents are significant problem given the frequency of their incidence and the magnitude of the associated costs(Kumar et al., 2010). 
Noise is the most common physical hazard in the industrial workplaces.

A report from the European Union mentions that about $28 \%$ of workers are exposed to noise level approximately between 85 and 90 Decibel Acoustic (dBA)The most common health problem due to exposure to noise is noise-induced hearing loss (NIHL), an irreversible but preventable disorder. NIHL is the second most common form of acquired hearing loss, after presbycusis. In thetile industry, because of some machinery, equipment, and tools, hazardous noise is frequently observed (Mostaghaci et al., 2013). Everybody in the workplace experiences some kind of frustrations, tensions or anxieties in relation to the general work environment. Stress can have serious consequences that affect both health and work performance. In terms of health, the current belief among many medical practitioners is that 50 or $70 \%$ of all physical illness are related to stress. Stress can cause depression, irritation, anxiety, fatigue, lowered self- esteem and reduced job satisfaction (Joy, 2014).

The occupational health nurse has special knowledge about understanding of the principles of safety, toxicology, industrial hygiene, epidemiology and environmental health, additionally, special skills in training in safety hazards, disaster planning for military with safety equipment, ability to plan and implement health and educational program. Occupational health nurse are also required to have up to update knowledge of current legal standards that affect the working population (Smith, 2013).

\section{Significance of the study}

According to Alim et al., (2014) who study respiratory health problems among the ceramic workers' in Dhaka. The study showed that notable higher prevalence of respiratory problems among the workers exposed to ceramic and tile dust, although the other potential environmental confounding factors could not be ruled out in the analysis workers. So the present study will identify the different health hazards and environmental factors that affects the studied sample health in tile factories.

\section{Subjects \& Methods \\ Aim of the study}

Assess studied sample knowledge about occupational health hazards in tiles factories and its' preventive measures.

\section{Specific objectives are to}

1-Assess studied sample knowledge about tile manufacturing hazards.

\section{Research question}

- Are the studied sample having knowledge about tiles manufacturing hazards and it's preventive measures?

\section{Research design}

Descriptive cross-sectional research design was used in the current study to assess studied sample

knowledge about occupational health hazards in tile factories and their preventive measures .

\section{A- Setting}

The study was carried out for workers in tile factories at Assiut Governorate. included four (4) industrial cities namely: Arab El_Awamer city in Abnoub included nineteen factories, El_Safa city in Biny Ghalib includedtwelvefactories, El_Zrapy city inOboteg a factory, Dash lout in Dirout included two factories $.50 \%$ of total numbers from factories which selected randomly for conducting the study .

\section{B-Sample}

Total coverage sample was used. The sample include All available workers from all previous mentioned setting. The total numbers of workers was414. Also the present study was conducted on 400 worker who accepted to participate on this study. As following :-

\begin{tabular}{|l|c|c|c|}
\hline Place of work & $\begin{array}{l}\text { Total No } \\
\text { of } \\
\text { Workers }\end{array}$ & $\begin{array}{c}\text { No of study } \\
\text { workers }(\mathbf{n}= \\
\text { 400) }\end{array}$ & \% \\
\hline $\begin{array}{l}\text { DDashloot- } \\
\text { Dairout }\end{array}$ & 23 & 23 & 5.7 \\
\hline $\begin{array}{l}\text { AEl-Zaraby - } \\
\text { Abou Teeg }\end{array}$ & 12 & 11 & 2.8 \\
\hline $\begin{array}{l}\text { AArab El- } \\
\text { Awamer }\end{array}$ & 229 & 216 & 54.0 \\
\hline $\begin{array}{l}\text { AEl-Safa- Bany } \\
\text { Ghaleb }\end{array}$ & 150 & 150 & 37.5 \\
\hline TTotal & 414 & 400 & $100 \%$ \\
\hline
\end{tabular}

\section{C-Tool of the study}

-Interview questionnaire sheet which developed by researchers after reviewing the relevant literature included two parts:-

Part 1: To collect information from workers about their socio-demographic characteristics such as

A)name, age, residence , qualification, marital status, level of education:

Professional history as years of experience, department, previous work,

Attending training courses,

Preventive measures in factories such as fire devices, communication line

B)Present and past health history as complains , health problems chronic disease, accident and surgery.

Part 2: To collect knowledge of workers about A)Occupational health hazards such as physical, chemical, mechanical, and psychological and biological hazardous. 
B) Safety measures such as industrial safety equipment and first aid equipment.

The scoring system was as follow:

A scoring system was designed for the assessment of knowledge was 17 questions, a score of 1 grade was given for each correct answer and a score of zero was given for an incorrect answer. The score of each item summed-up and then converted into a percent score as following: Poor knowledge; score less than $50 \%$, Fair knowledge; if score is from $50-70 \%$ and Good knowledge ; if score more than 70\%(Abd Elzaher et al., 2014).

Methodology

I-Administrative phase

An official letter approval obtained from dean of the Faculty of Nursing Assiut University to Assiut governorate, directors of industrial cities and directors of tile factories. This letter included a brief explanation of the objectives of the study.

\section{II-Pilot Study}

A pilot study was carried out before starting data collection on $10 \%$ of studied sample from two setting were excluded from the sample for presence of some modification in the clarity of statement . It's aimed to test the clarity and applicability of the tool to detect any ambiguity in the study tools. The pilot study has also served to estimate the time required to fill the interview questionnaire sheet

Validity of tool: The tools were translated to English language and reviewed to ascertain their validity by five experts in community health nursing science who reviewed the instrument for clarity, relevance, comprehensiveness, understanding and applicability.

Reliability of tool: Was assessed using alpha Cronbach test to test the internal consistency $\mathrm{K}=.0834, \mathrm{P}=.0702$

\section{II- Data collection Phase}

\section{Ethical consideration}

Research proposal will be approved from Ethical Committee in the Faculty of Nursing. $\square \square$ There is no risk for study subject during application of the research. The study will follow ethical principles in clinical research. Written consent will be obtained from the directors and oral informed consent willbe obtained from studied sample that are willing to participate in the study, after explaining the nature and purpose of the study .Confidentiality and anonymity will be assured. Studied sample have the right to refuse to participate and or withdraw from the study without any rational any time.

\section{Field work}

Data was collected in the period from $15^{\text {st } J u n e, ~} 2017$ to $18^{\text {th }}$ September, 2017 . The researchers introduce themselves and explain the purpose of the study for the studied sample. The average of time taken for completing each sheet was around 15-20 minutes depending on the persons' response to questions. The data was collected at Saturday and Sunday, at morning. About (10-12) sheets/day.

\section{Statistical analysis}

The collected data were tabulated and analyzed by computer using the "Statistical Package for the Social Sciences" (SPSS) version 19. Descriptive statistics such as frequency, mean, and standard deviation were utilized to analyze data. Relevant statistical tests of significance were used to identify the relations among the study variables. Chi square and correlations were used to compare difference in the distribution of frequencies between different groups. It was considered significant when $\mathrm{p}$ - values were less than 0.05 . And to identify the significance of the relations, associations, and interactions among variables. 


\section{Result}

Table (1) Distribution of the studied sample regarding to their socio-demographic characteristics in tile factories $(\mathrm{No}=\mathbf{4 0 0})$.

\begin{tabular}{|c|c|c|}
\hline Variables & No. $(n=400)$ & $\%$ \\
\hline \multicolumn{3}{|l|}{ Age: (years) } \\
\hline$<30$ & 142 & 35.5 \\
\hline $30 \leq 35$ & 119 & 29.8 \\
\hline$>35$ & 139 & 34.7 \\
\hline Mean \pm SD (Range) & \multicolumn{2}{|c|}{$32.16 \pm 6.98(16.0-46.0)$} \\
\hline \multicolumn{3}{|l|}{ Residence: } \\
\hline Urban & 197 & 49.3 \\
\hline Rural & 203 & 50.7 \\
\hline \multicolumn{3}{|l|}{ Marital status: } \\
\hline Single & 129 & 32.2 \\
\hline Married & 271 & 67.8 \\
\hline \multicolumn{3}{|l|}{ Level of education: } \\
\hline Illiterate & 10 & 2.5 \\
\hline Read \& write & 66 & 16.5 \\
\hline Basic education & 19 & 4.8 \\
\hline Secondary education & 305 & 76.2 \\
\hline \multicolumn{3}{|l|}{ Years of experience: (years) } \\
\hline$<5$ & 123 & 30.7 \\
\hline $5-10$ & 186 & 46.5 \\
\hline$>10$ & 91 & 22.7 \\
\hline Mean \pm SD (Range) & \multicolumn{2}{|c|}{$7.39 \pm 4.27(6 \mathrm{~m}-20 \mathrm{y})$} \\
\hline \multicolumn{3}{|l|}{ Department } \\
\hline Preparation of raw materials & 55 & 13.8 \\
\hline Manufacturing & 180 & 45.0 \\
\hline Drying & 53 & 13.2 \\
\hline Finishing & 112 & 28.0 \\
\hline \multicolumn{3}{|l|}{ Attending training courses } \\
\hline Yes & 75 & 18.7 \\
\hline No & 325 & 81.3 \\
\hline \multicolumn{3}{|l|}{ Previous work } \\
\hline Yes & 144 & 36.0 \\
\hline No & 256 & 64.0 \\
\hline Mean \pm SD (Range) & \multicolumn{2}{|c|}{$7.39 \pm 4.27(6 \mathrm{~m}-20 \mathrm{y})$} \\
\hline
\end{tabular}


Table (2): Distribution of the studied sample regarding to their preventive measures in tile factories $(\mathrm{No}=400)$.

\begin{tabular}{|c|c|c|}
\hline Variables & No. $(n=400)$ & $\%$ \\
\hline \multicolumn{3}{|l|}{ Reducing working time in the high temperature environment } \\
\hline Yes & 104 & 26.0 \\
\hline No & 189 & 47.2 \\
\hline Sometimes & 107 & 26.8 \\
\hline \multicolumn{3}{|l|}{ Presence of fire protection devices } \\
\hline Yes & 395 & 98.7 \\
\hline No & 5 & 1.3 \\
\hline \multicolumn{3}{|l|}{ Checking the validity of the fire tools } \\
\hline Yes & 390 & 98.7 \\
\hline No & 5 & 1.3 \\
\hline \multicolumn{3}{|l|}{$\begin{array}{l}\text { Presence offast communication devices between production } \\
\text { department }\end{array}$} \\
\hline Yes & 388 & 97.0 \\
\hline No & 12 & 3.0 \\
\hline \multicolumn{3}{|c|}{ Presence of a person to follow up necessary safety and security needs } \\
\hline Yes & 313 & 78.3 \\
\hline No & 87 & 21.7 \\
\hline Person responsible for safety and security needs. & 313 & \\
\hline Industrial security supervisor & 7 & 2.2 \\
\hline Administrator & 306 & 97.8 \\
\hline Other personality listed & 0 & 0.0 \\
\hline \multicolumn{3}{|c|}{$\begin{array}{l}\text { Presence of specialists for operation and maintenance of device and } \\
\text { equipment }\end{array}$} \\
\hline Yes & 43 & 10.7 \\
\hline No & 357 & 89.3 \\
\hline \multicolumn{3}{|l|}{ Presence of a person responsible for workers' health awareness } \\
\hline Yes & 132 & 33.0 \\
\hline No & 268 & 67.0 \\
\hline Person who is responsible for workers' health awareness & 3 & \\
\hline Doctor & 132 & 100.0 \\
\hline \multicolumn{3}{|l|}{ Presence of first aid } \\
\hline Yes & 273 & 68.3 \\
\hline No & 127 & 31.7 \\
\hline \multicolumn{3}{|l|}{ Person who Perform first aid } \\
\hline Doctor & 4 & 1.5 \\
\hline Industrial security supervisor & 39 & 14.3 \\
\hline Trained worker & 6 & 2.2 \\
\hline Any worker & 224 & 82.0 \\
\hline \multicolumn{3}{|l|}{ Measures which done in case of injury } \\
\hline First aids are provided & 218 & 54.5 \\
\hline Transfer to the nearest hospital & 182 & 45.5 \\
\hline
\end{tabular}


Table (3): Distribution of the studied sample regarding to their knowledge about health hazards in tile factories $(\mathrm{No}=\mathbf{4 0 0})$.

\begin{tabular}{|l|c|c|}
\hline \multicolumn{1}{|c|}{ Variables } & No. $(\mathbf{n}=\mathbf{4 0 0})$ & \% \\
\hline Skin problems & & \\
\hline Good & 372 & 93.0 \\
\hline Fair & 21 & 5.3 \\
\hline Poor & 7 & 1.7 \\
\hline Hearing problems & 337 & 84.2 \\
\hline Good & 55 & 13.8 \\
\hline Fair & 8 & 2.0 \\
\hline Poor & & \\
\hline Stress \&headache & 320 & 80.0 \\
\hline Good & 20 & 5.0 \\
\hline Fair & 60 & 15.0 \\
\hline Poor & & \\
\hline Respiratory problems the most common among workers & 297 & 74.3 \\
\hline Good & 26 & 6.5 \\
\hline Fair & 77 & 19.2 \\
\hline Poor & & \\
\hline Respiratory problems result from exposure to silicate dust \&feldspar & 39 & 9.8 \\
\hline Good & 37 & 9.2 \\
\hline Fair & 324 & 81.0 \\
\hline Poor & & \\
\hline Accidents & 104 & 26.0 \\
\hline Good & 282 & 70.5 \\
\hline Fair & 14 & 3.5 \\
\hline Poor & & \\
\hline Problems of the digestive system & 78 & 19.5 \\
\hline Good & 190 & 47.5 \\
\hline Fair & 132 & 33.0 \\
\hline Poor & & \\
\hline Occupational toxicity & 32 & 3.8 \\
\hline Good & 343 & 85.5 \\
\hline Fair & & \\
\hline Poor & & \\
\hline & & \\
\hline
\end{tabular}

Table (4):Distribution of the studied sample regarding to their knowledge about occupational preventive measures in tile factories $(\mathrm{No}=400)$.

\begin{tabular}{|l|c|c|}
\hline \multicolumn{1}{|c|}{ Variables } & No. $(\mathbf{n = 4 0 0})$ & \% \\
\hline The workplace must be vacuumed using: & & \\
\hline Suction sweep equipment & 50 & 12.5 \\
\hline Wet synagogues & 167 & 41.7 \\
\hline Suction sweep equipment \& Wet synagogues & 3 & 0.8 \\
\hline Dry synagogue* & 180 & 45.0 \\
\hline Raw materials are transported through: & & \\
\hline Closed systems such as spiral equipment & 51 & 12.8 \\
\hline Open Systems* & 349 & 87.2 \\
\hline Personal protective tools:\# & & \\
\hline Apron & 45 & 11.3 \\
\hline Shoes & 190 & 47.5 \\
\hline Gloves & 341 & 85.3 \\
\hline
\end{tabular}




\begin{tabular}{|l|c|c|}
\hline \multicolumn{1}{|c|}{ Variables } & No. (n= 400) & \% \\
\hline Masks & 303 & 75.8 \\
\hline Personal protective tools are personal custody & 6 & 1.5 \\
\hline Yes & 394 & 98.5 \\
\hline No & & \\
\hline Methods of storing raw materials correctly & 29 & 7.2 \\
\hline Use closed silos & 257 & 64.3 \\
\hline Use wind protection methods & 107 & 26.7 \\
\hline Use closed silos \& Use wind protection methods & 7 & 1.8 \\
\hline Do not separate storage areas from operating zones* & & \\
\hline $\begin{array}{l}\text { The main sources of emissions the particulate matter and dust } \\
\text { include \# }\end{array}$ & & \\
\hline Handling of raw materials & 287 & 71.8 \\
\hline Crushing and grinding & 316 & 79.0 \\
\hline Spraying operations & 6 & 1.5 \\
\hline
\end{tabular}

*In correct answer

\#More than one answer

Table (5): Relationship between total score of the studied sample knowledge regarding to occupational health hazards and their personal characteristics in tile factories $(\mathrm{No}=400)$.

\begin{tabular}{|c|c|c|c|c|c|c|c|c|}
\hline \multirow{3}{*}{$\begin{array}{l}\text { Socio-demographic } \\
\text { characteristics }\end{array}$} & \multicolumn{6}{|c|}{ Knowledge level } & \multirow{3}{*}{$\mathbf{X}^{2}$} & \multirow{3}{*}{ P-value } \\
\hline & \multicolumn{2}{|c|}{$\begin{array}{c}\begin{array}{c}\text { Poor } \\
(n=233)\end{array} \\
\end{array}$} & \multicolumn{2}{|c|}{$\begin{array}{c}\text { Fair } \\
(\mathbf{n}=\mathbf{1 0 7})\end{array}$} & \multicolumn{2}{|c|}{$\begin{array}{c}\text { Good } \\
(n=60)\end{array}$} & & \\
\hline & No & $\%$ & No & $\%$ & No & $\%$ & & \\
\hline \multicolumn{7}{|l|}{ Age: (years) } & \multirow{4}{*}{59.63} & \multirow{4}{*}{$0.000 *$} \\
\hline$<30$ & 116 & 81.7 & 19 & 13.4 & 7 & 4.9 & & \\
\hline $30-35$ & 64 & 53.8 & 30 & 25.2 & 25 & 21.0 & & \\
\hline$>35$ & 53 & 38.1 & 58 & 41.7 & 28 & 20.1 & & \\
\hline Residence: & & & & & & & \multirow{3}{*}{4.10} & \multirow{3}{*}{0.129} \\
\hline Urban & 120 & 60.9 & 44 & 22.3 & 33 & 16.8 & & \\
\hline Rural & 113 & 55.7 & 63 & 31.0 & 27 & 13.3 & & \\
\hline \multicolumn{7}{|l|}{ Marital status: } & \multirow{3}{*}{36.73} & \multirow{3}{*}{$0.000^{*}$} \\
\hline Single & 103 & 79.8 & 18 & 14.0 & 8 & 6.2 & & \\
\hline Married & 130 & 48.0 & 89 & 32.8 & 52 & 19.2 & & \\
\hline \multicolumn{7}{|l|}{ Level of education: } & \multirow{5}{*}{26.28} & \multirow{5}{*}{$0.000 *$} \\
\hline Illiterate & 6 & 60.0 & 3 & 30.0 & 1 & 10.0 & & \\
\hline Read \& write & 28 & 42.4 & 31 & 47.0 & 7 & 10.6 & & \\
\hline Basic education & 7 & 36.8 & 10 & 52.6 & 2 & 10.5 & & \\
\hline Secondary & 192 & 63.0 & 63 & 20.7 & 50 & 16.4 & & \\
\hline \multicolumn{7}{|l|}{ Department } & \multirow{5}{*}{37.38} & \multirow{5}{*}{$0.000 *$} \\
\hline Preparation of raw materials & 31 & 56.4 & 14 & 25.5 & 10 & 18.2 & & \\
\hline Manufacturing & 79 & 43.9 & 68 & 37.8 & 33 & 18.3 & & \\
\hline Drying & 43 & 81.1 & 8 & 15.1 & 2 & 3.8 & & \\
\hline Finishing & 80 & 71.4 & 17 & 15.2 & 15 & 13.4 & & \\
\hline \multicolumn{7}{|l|}{ Attending training courses: } & \multirow{3}{*}{11.07} & \multirow{3}{*}{$0.004 *$} \\
\hline Yes & 34 & 45.3 & 21 & 28.0 & 20 & 26.7 & & \\
\hline No & 199 & 61.2 & 86 & 26.5 & 40 & 12.3 & & \\
\hline
\end{tabular}

There is significant difference P value $<0.05-\quad X 2$ chi-square test was used 


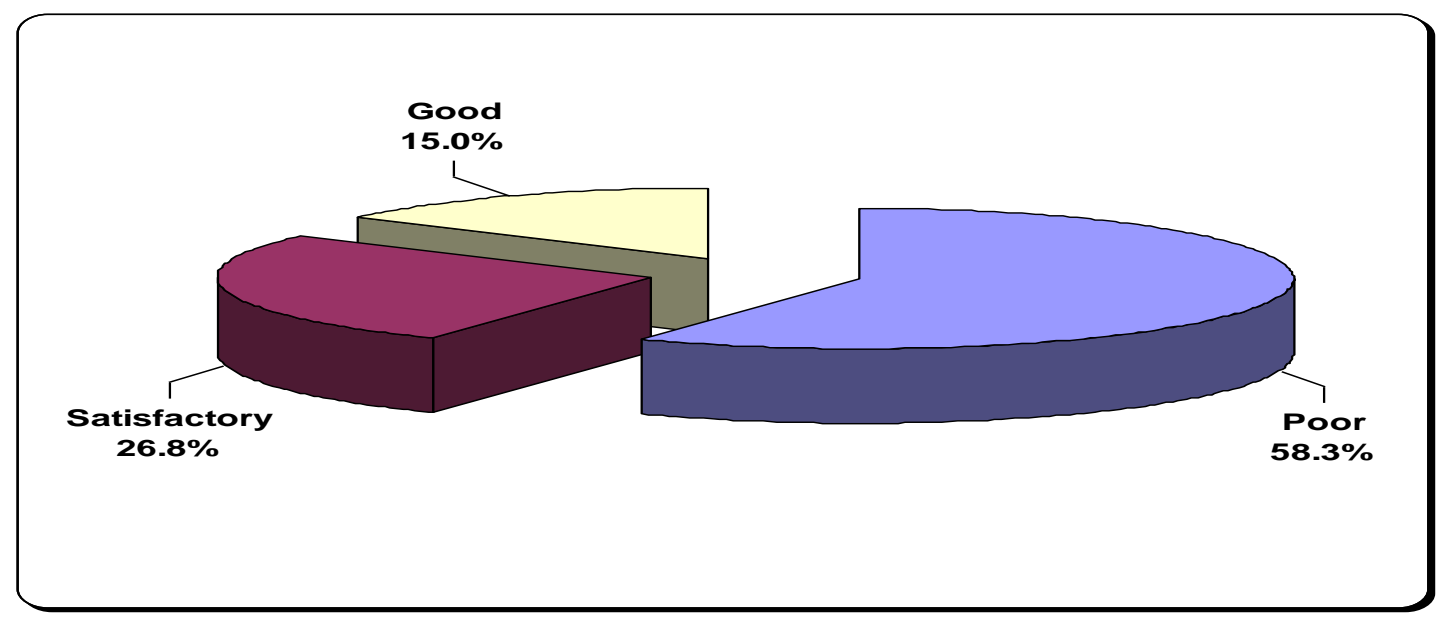

Fig (1): Distribution of studied sample regarding to their total score of knowledge about occupational health hazards in tile factories .

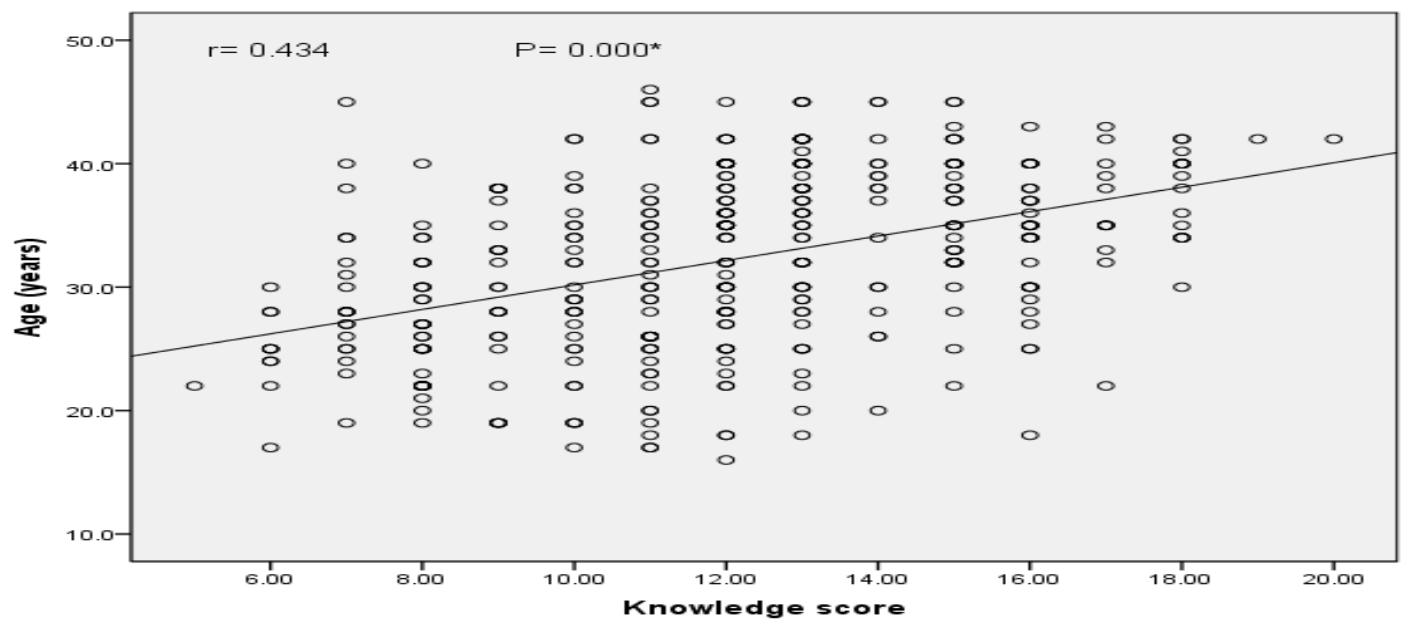

Fig. (2): Correlation between total score of the studied sample knowledge and age (years) regarding to occupational health hazards in tile factories.

Table (1): Shows distribution of the studied sample regarding to their socio-demographic characteristics in tile factories, it was founded that $35.5 \%$ of the studied sample aged between $<30$ years followed by $34.7 \%$ aged $>35$ years and 29.8 aged $30 \leq 35$ years old. According to their residence, it noticed that $50.7 \%$ of them were from rural community. Regarding the marital status, it was observed that $67.8 \%$ of the them were married. Also, $76.2 \%$ of them had secondary education. While only $2.5 \%$ were illiterate. According to department, it was noticed that $45.5 \%$ of the workers were working at manufacturing of tile followed by $28.0 \%$ of them were working at finishing. As regard their years of experience at work, it was noticed that $30.7 \%$ of them had job experience less than 10 years .according to attending training course, it was noticed that only $18.7 \%$ of them had attended training while $81.3 \%$ of them didn't attend any training courses. Regarding previous job it was noticed that $64.0 \%$ of the workers didn't have a previous work before working in tile factory while $36.0 \%$ worked before.

Table (2): Illustrates distribution of the studied sample regarding to their preventive measures tile factories, it was observed that $26.0 \%$ of studied sample mention that working time was reduced in the high temperature environment. Also, $98.7 \%$ of them, reported presence of fire protection devices and there are checking the validity of the fire tools. Also, it was noticed that $97.0 \%$ of them reported that there are communication devices between production lines . Moreover $78.3 \%$ of them reported that there are an official to follow up necessary safety and security needs . Also, the table show that $89.3 \%$ of them reported that there is no specialist for operation and maintenance of device and equipment. According to first aid, it was noticed that $68.3 \%$ of them mentioned that there was present. 
Table (3): Illustrates distribution of the studied sample regarding to that knowledge about health hazards in tile factories, it revealed that $93.0 \%$, $84.3 \%, 80.0 \%, 74.3 \% 26.5 \%, 19.5 \%$ and $3.8 \%$ had good knowledge about skin, hearing, stress, headache, respiratory problems accidents, digestive system problems and occupational toxicity.

Table (4): Illustrates distribution of the studied sample regarding to their knowledge about occupational preventive measures in tile factories, it revealed that $45.0 \%$ of the studied sample answered using dry synagogue in work place vacuuming and $87.2 \%$ reported that open systems is used in transportation of raw materials. Also, it was observed that $85.3 \%$ of the studied sample reported that gloves use as a personal protective tools in tile factory. while $11.3 \%$ of them reported apron . Also, $98.5 \%$ of them reported that personal protective equipment isn't custody. The results also revealed that $64.3 \%$ of the reported studied sample using wind protection methods in storing of raw materials As regard to studied sample knowledge about the main sources of emissions of particulate matter and dust $79.0 \%$ of them stated that crushing and grinding, ,while $71.8 \%$ reported handling of raw materials and $1.5 \%$ reported spraying operations.

Table (5): Reveals that relationship between total score of studies sample knowledge about occupational health hazards and their sociodemographic characteristics in tile factories at Assuit governorate, this table shows that there were statistical significant difference between the total score of studied sample knowledge about occupational health hazards and studied sample age, marital status, level of education, department, and attending training courses $\mathrm{P}$ value $(0.000,0.000$ , 0.000 , and 0.004) respectively .

Fig (1): Clear that $58.3 \%$ of studies sample had poor knowledge about occupational health hazards in tile factories, while $26.8 \%$ of them had fair knowledge and $15.0 \%$ had good knowledge.

Fig (2): It was founded that, a positive correlation between total score of studies sample knowledge and age (years) regarding occupational health hazards in tile factories.. with high statistically significant difference $(r=0.434 ; \mathrm{p}=0.000)$.

\section{Discussion}

In the workplace, working conditions are essential to the health of workers. The organization of work reduces the chances of avoiding risks, mitigating them or eliminating them while performing their duties (Luiz et al., 2016) Occupational Risk is any possibility that some element or existing circumstances in a given process or work environment can cause damage to health, whether through accident, disease or the suffering of workers (Silva et al., 2012).

This study aimed to assess knowledge of workers' toward occupational health hazards in tile factories. The results of the present study revealed that more than one third of the studied sample their age ranged between 30-35years old. This finding inconsistent with study conducted by Luiz et al., (2016) about Knowledge of Workers on Occupational Hazards in the Industry of Ceramics. who mentioned that most of the workers between 20 and 30 years old. Moreover the study which conducted by Krishna et al., (2018) about Practice Related to occupational Health and Safety among Workers of Brick Factories who found that more than one third of the studied sample were at the age of 25-29 years. Also, the study which conducted by Alim et al., (2014) about Respiratory Health Problems among the Ceramic Workers in Dhaka reported that more than half $(53.0 \%)$ of the studied sample were belonged to the age group 14-30 years. Regarding the marital status, it was observed that more than two thirds of the studied sample was married. These finding agree with study carried by Alim et al., (2014) about Respiratory Health Problems among the Ceramic Workers in Dhaka who mentioned that the majority of workers were married.

In the present study more than three quarters of the studied sample had secondary education. While only $2.5 \%$ were illiterate. From researcher point of view education is important in general and in particular for this group to know how to read safety instructions and reducing hazards. These result was contrast with study conducted by Luiz et al., (2016) about Knowledge Workers on Occupational Hazards in the Industry of Ceramics in Brazil, who reported that three quarters of the studied sample their level of education, had completed elementary school, and one quarter of workers had high school diploma.

Regarding to their years of experience, the present study revealed that the studied sample years of experience at work was less than half of them had job experience less than 10 years. This is in agreement withthe study conducted by Alim et al., (2014) about Respiratory Health Problems among the Ceramic Workers in Dhaka who reported that, length of service in years from 1-10 years.

As regard to their knowledge regarding safety and security in tile factories, the present study represented that the majority of the studied sample reported that the presences of fire protection devices, checking the validity of the fire tools, the person is administrator and there was communication devices between production lines, Also, more than three quarters of the studied sample reported that there was an official to follow up necessary safety and security needs. 
These precautions are excellent for the studies sample to be known which help them to prevent the incidence of work hazards.

According to the first aid, it was noticed that more than two thirds of the studied sample mentioned that there was first aid materials in their work setting. This is a good thing because they know that there was first-aid kits in their workplace, so they use them immediately after any injury. This finding disagree with the study which conducted by Krishna et al., (2018) about Practice Related to occupational Health and Safety among Workers of Brick Factories who found that none of the studies sample keep first aid kit in their work place for emergency use.

As regard knowledge of the studied sample about health problems in tile factories, it revealed that the majority of them had knowledge about stress, headache, skin problems and hearing problems. This finding disagree with study carried out by Mehrdad et al., (2013) about the effect of Workplace Noise on Hearing Ability in Tile and Ceramic Industry Workers in Iranwho stated that noise as a common physical exposure in many industrial workplaces may lead to various health effects such as hearing loss. Also, the detection of hazards and risk assessment must be considered to identify how they could affect workers and the company to develop and implement appropriate prevention and protective measures (Luiz et al., 2016)

As regard to the total knowledge of the studied sample about occupational health hazards in tile factories at Assiut governorate. The present study revealed that more than half of studied sample have poor knowledge about occupational health hazards in tile factories, while more than one quarter of them have fair knowledge and $15.0 \%$ have good knowledge. This result from the researcher opinion is due to the majority of the studied sample did not attended any training courses for workers about occupational hazards and industrial risk prevention and use of machines. This means the urgency need to continuously training for workers.

Regarding to the relationship between total score of the studied sample knowledge about occupational health hazards and their personal characteristics in tile factories at Assiut governorate, the data illustrated that there were statistical significant difference between the total score of studies sample knowledge about occupational health hazards with workers' age, marital status, level of education, department and attending training courses. This result may be due to the older the workers were more experienced and knowledgeable about occupational health hazards.

The present study illustrated that, there was a positive correlation between total score of the studied studies sample knowledge with age (years) \& duration of current work (years) regarding occupational health hazards in tile factories, with high statistically significant difference .

\section{Conclusions}

According to the finding and research question .It was concluded that more than half of the studied sample have poor knowledge about occupational health hazards and it's preventive measure in tile factories, while more than one quarter of them have fair knowledge. This point has met the answer of the research question. There were statistical significant difference between the total score of the studied sample knowledge about occupational health hazards and workers' age, marital status, level of education, department, and attending training .

\section{Recommendations}

1. Provide training program and health education to the workers in tile factories to increase their knowledge about hazards and complications from persistent exposure to toxic raw materials used in manufacturing of tiles.

2. Provide education \& training programs regularly about using of personal protective equipment.

3. Periodic medical examination should be performed to all workers

4. Dissemination of a guideline book for workers in tile factories about the different occupational hazardous and it's prevention.

\section{References}

1. Abd El Maaboud, R., Mohamed, Z., Gearge, \& S., Ez-Eldine, A., (2015): Lead and Cadmium Toxicity in Tile Manufacturing Workers at Assiut , Egypt, Arab Journal of Forensic Sciences and Forensic Medicine, Vol(1),no29, PP299-311.

2. AbdElzaher, O., Qayed, M., Mohamed, S., \& Mohamed, A., (2014): Farmer's knowledge, attitude and practice about pesticides in a village of abnub district. Assiut Governorate. Thesis Master Degree in Community Health Nursing at Faculty of Nursing. Assiut University.

3. Alim, M., Biswas, M., \& Hossain, M., (2014): Respiratory Health Problems Among The Ceramic Workers in Dhaka -Bangladesh, Farridpur Medical College Journal, vol( 9), no 4, pp19-23.

4. Ashraph, J., Kinyua, R., \& Mugambi, F., (2013): Health Effects Of Lead Exposure Among Jua Kali Workers In Mombasa, Kenya .International Journal of Medicine and Medical Sciences Vol (5), pp.24-29, Available online at http://www .academicjournals.org . 
5. Edilaura, N., Regina, M., \& Clovis, B., (2011): Respiratory symptoms as health status indicators in workers at ceramics manufacturing facilities.J. bras PneumolJournal. Vol (37) pp.36-45.

6. Environmental Health \& Safety Guidelines, (2013): Ceramic Tile and Sanitary Ware Manufacturing. http//www .acgih.org.com.

7. Joy, J., (2014): Astudy of work stress and coping strategies among tile factory workers ,international journal of scientific and research publication, vol (3), http//WWW.ijsrp.org

8. Krishna, B., Sushmita, K., \& Kshitij, K., (2018): Practice Related to occupational Health and Safety among Workers of Brick Factories at Bhaktapur, NEPAL. International Journal of Research - GRANTHAALAYAH. Vol.6 (Iss.3). Pp. $98-104$.

9. Kumar, G., Rathnakar, U., \& Kumar, H., (2010): Epidemiology of accidents in tile factories of Mangolare city, Indian Journal of Community medicine, vol (35), pp78-81.

10. Luiz, C., Raissa, E., Larissa, M., Yanna Gomes, S., Soraya M., \& Jovanka, B., (2016): Knowledge Workers on Occupational Hazards in the Industry of Ceramics in Brazil. Vol. 9 No. 137. Pp: 1 - 8. doi: 10.3823/2008

11. Mehrdad, M., Seyyed, J., Amir, H., Maryam, B., Abolfazl, M., \& Mohammad, H., (2013): Effect of Workplace Noise on Hearing Ability in Tile and Ceramic Industry Workers in Iran: A 2Year Follow-Up Study. The Scientific World Journal, Volume 2013, Article ID 923731, 7 pages, http://dx.doi.org/10.1155/2013/923731

12. Mohammadi, S., Dehgan, F., Sadeghi, Z., \& Attarchi, M., (2009): Respiratory Compalaints And Spirometric Parameters In Tile And Ceramic Factory in Iran workers , National Research institute of Tuberculosis and Lung disease, vol 8, no 16 , pp9-25.

13.Smith, F., (2013): Community public health nursing practice, health for families and population, 5th ed Elsevier Sounders, pp.251252.symbol effects in accidents with sharp instruments. Brazilian Journal of Nursing ,65(5): 809-814

14. Silva, E., Lima, M., \& Marziale, M., (2012): The concept of risk and its symbol effects in accidents with sharp instruments. BrazilianJournal of Nursing ,65(5): 809-814

15. Wadho, L., (2012): Civil Engineering Material, available athttp//www. Slide share.net. 